\title{
ARTHUR COTTON AND IRRIGATION IN TASMANIA 1839-43
}

\author{
by G. Blackburn
}

BLACKBURN, G., 1985 (31:vii): Arthur Cotton and irrigation in Tasmania 1839-43. Pap. Proc. R. Soc. Tasm. 119: 1-5. https://doi.org/10.26749/rstpp.119.1 ISSN 0080-4703, 78 Allinga Ave, Glenunga, South Australia, 5064.

Cotton, an officer of the East India Company with experience of irrigation, visited Tasmania for periods totalling three years. His influence was important in ga ining acceptance of irrigation as an a id tocereal production and the livestock ind ustry. Details are given of his Tasmanian work, which had particular significance there for its emphasis on water conservation.

Key Words: Irrigation, Tasmania, Arthur Cotton.

\section{INTRODUCTION}

Arthur Thomas Cotton (1803-99) was the first engineer skilled inirrigation to visit Tasmania. He took a positive but unofficial interest in irrigation there during 1838-40 and 1841-43. A scheme for one locality was then successful, irrigation was extended by landowners in other districts, and work commenced on a major scheme for water conservation and irrigation. Although that project was soon abandoned during an economic recession, irrigation continued on several estates, as shown by Martelli (1861).

The early establishment of irrigation in Tasmania was ignored in Deakin's (1892) review of Australian irrigation, which mentions many individual irrigators, and in numerous accounts of large Australian schemes for irrigation. Roberts (1924, p.345), however, mentioned the abortive Tasmanian project. He gave credit for it to Major Cotton, apparently unaware that two brothers Captain (Arthur) and Major (Hugh) Cotton were associated with Tasmanian irrigation, for he did not indicate that Captain Cotton wrote the earliest of the papers noted by him as pertaining to Major Cotton. Captain Cotton's paper was published by the Tasmanian Society, and some early contributions on Tasmanian affairs certainly referred to him. Recent articles on the historic Long Marsh dam site (Scarborough and Brand 1975, Gowlland 1980) have given him some prominence. This paper attempts to clarify Arthur Cotton's role in the early years of Tasmanian irrigation.

The grandson of a baronet, Cotton grew up near Reading, England. In 1818 he entered Addiscombe College, the military academy of the East India Company, and was trained as a military engineer. After arrival in Madras in 1821, he worked on engineering projects, fought in the Burma Wars of 1824-25, and was later occupied mainly with irrigation works in southern India. He achieved great distinction as an engineer (Sandes 1935, p.28).

\section{VISITS TO TASMANIA}

Arthur Cotton's three visits to Australia were mentioned by his daughter (Hope 1900). The East India Companyat times granted long leave on sick certificate to Cotton. On the first such period he was able to return to England, but service rules ensured that next time his choice of travel abroad was limited to South Africa or Australia (Hope 1900 , pp.20-22). Britons in India were then being attracted to Tasmania (Henderson 1832) and Sydney Cotton (Pike 1966-67, v. 1,p.250) could have given fraternal encouragement about that colony. All of his visits to Australia occurred during periods of sick leave, for which the dates have been established. His arrivals in Tasmania are recorded in archives.

Captain Cotton reached Hobart in the Guillardon on 12 December 1838 with leave until April 1840, later extended to October 1840. His host in the colony was given as Captain Beecher (Hope 1900, p.23), a name not found in records of arrivals in Tasmania. However, for 25 August 1838 those records list "Becher", an homophonous variant of Beecher. Lieutenant Henry Murray Becher in March 1838 took leave for two years to Australia from the Bengal Native Infantry (Hodson 1927, p.116); like Arthur Cotton he had been educated at Addiscombe College (Vibart 1894, p.670). Soon after Cotton's arrival he was introduced by Captain Beecher (?Becher) to Elizabeth Learmonth. Later he became engaged to this daughter of a former merchant in Calcutta. Lady Hope also mentioned that herfather was a friend of the Franklins and a frequent visitor to Government House.

Arthur Cotton was at first particularly concerned with the performance of a steam engine. The 
Madras Government in a public citation of October 1838 recognized his development of a 'rotatory' engine, apparently one of the numerous precursors of Parson's steam turbine (Dickinson 1963, pp. 185-92). During an experiment with his engine soon after arrival in Hobart, Cotton was seriously injured by explosion of the boiler; he was then unable to walk for months. He convalesced at first in a hotel, from which he moved to a home on the Derwent a few kilometres out of town. Later he stayed with a family 'in the centre of the island' and then moved to Norfolk Plains (Longford). Cotton returned to India by the expiry of his leave in October 1840.

On Cotton's second visit, he landed at Launceston from the Nerio on 6 October 1841 . He was married by Rev. John Lillie to Elizabeth Learmonth in her father's house at Green Ponds (Kempton) on 29 October. He had been given leave until October 1842; it was later extended to April 1843. Hope $(1900$, p.24) did not name a locality where the Cottons lived, but a letter she quoted shows Cotton's intention to take a small farm adjoining a parsonage and to use an engine for irrigation there. Norfolk Plains was apparently the main locality, for that was the address given in Cotton's letter of January 1843 reported in the Tasmanian Journal of Natural Science (v.2, no.6, p.76) and that town then had a parsonage, occupied by Rev. R.R. Davies and known as "Pinefield" (Pike 1966-67, v.2, p.143). Captain Cotton left Tasmania with his wife and daughter in time to take up duty again in April 1843

Cotton's last visit was in 1848-50. He and his family then spent a few weeks in Tasmania before leaving for Victoria in February 1849.

\section{IRRIGATION}

An appreciation of Arthur Cotton's contribution to Tasmanian irrigation can be gained by considering its progress before, during, and after his visits. There are many references to this matter in unofficial and official documents or publications made in Tasmania and elsewhere. Hope (1900) only referred briefly to her father's interest in Tasmanian irrigation, in connection with his second visit. The long review by Cotton (1842a) was probably the earliest contribution devoted to irrigation to be published in an Australian colony; it is considered below in some detail. Evidence of Tasmanian irrigation clearly preceding Cotton's arrival is fragmentary and apparently relates only to places near the Derwent River: on the farm reclaimed by Governor Arthur near Bridgewater (Bethell n.d., p. 109) and at New Norfolk before February 1836 (Backhouse 1843, pp.348-9).

\section{Cotton's review}

Arthur Cotton's paper (Cotton 1842a) appeared in the second and third issues of the journal published by the Tasmanian Society and his first instalment was noted in the Launceston Advertiser of 18 November 1841 . Cotton, always named A.F. Cotton, was listed as either a corresponding or a resident member (at Norfolk Plains) in early issues of the Journal.

In his paper, Arthur Cotton touched occasionally on what he knew of irrigation as then practised in Tasmania, and gave detailed attention to prospects for extensive irrigation in the colony and the technical measures involved. He mentioned that several landowners in different parts of the island were obtaining better crops of grass and wheat by irrigation and that this practice had also reduced losses due to frost and insect damage. These acknowledgments of existing irrigation compare with those of Bethell (n.d., p.72). concerning irrigation in the 1830 s on three properties, and of Burn (1840b).

Prospects for irrigation in Tasmania were considered by reference to topographic, hydrographic, and climatic features of the island. Cotton had 'passed through it (the colony) in various directions' (p.177) and knew Lake Sorell and various streams: the Clyde, Derwent, Jordan, Lake, Macquarie, Russell Falls, and South Esk Rivers. He had not heard in Tasmania of an individual river or creek which has not in the upper part of its course a proportionately extensive lake or swamp' (p.84), a situation in marked contrast to southern India. Because of this Tasmanian feature, the provision of a very short bank would allow a large body of water to be collected for release in the dry season. In this connection he mentioned a timber dam seen at the head of the Clyde River, on what he identified as Lake Sorell, and a larger dam on a branch of the Macquarie River.

Arthur Cotton compared the climate of Tasmania with that of Madras, making use of the limited rainfall records for the island and his own estimate of evaporation from Lake Sorell. This led to the conclusion that irrigation would help production over a full year on 120000 ha of the inland low country (p.85). In his view the Lake River gave the greatest scope for irrigation.

In India, Cotton's irrigation work was concerned with integrated schemes, but his paper in Tasmania shows obvious a wareness of the interests of individual land owners, many of whom he found ready to proceed singly with irrigation. He acknowledged that some had already constructed excellent works despite their lack of specialised knowledge (p.179), but others were diffident about the procedure for irrigation (p.181). 
Much of the second part of the paper deals with measures for controlling water resources and with alternative means of delivery; by gravitation or by lift using machines powered by steam, bullocks, or wind. One of his last points was the need for state control of water resources, particularly in reference to Tooms Lake in the Macquarie River system.

Personal references at the end of his paper and in the postscript indicate the nature and time of Cotton's consideration of Tasmanian irrigation. Firstly he mentioned his current ailments and his serious accident in the colony. These remarks, consistent with his period of sick leave, show some incapacity for mental and physical exertion; they suggest a contemplative approach to his subject. Secondly, the postscript establishes that the paper was written before the author left Norfolk Plains during his first visit and therefore represented conditions no later than mid-1840.

\section{Projects involving Macquarie River}

More than 50000 ha of low country traversed by the Macquarie River system in the Tasmanian Midlands has an average annual rainfall less than $500 \mathrm{~mm}$ (Anon. 1972, p.10), which is often insufficient in summer for crop and pasture growth. The main parts of the upper Macquarie River were first known only as its northern and southern branches, but the former is now identified as the Macquarie River and the latter as Tooms River. That stream drains Tooms Lake, which now covers approximately 600 ha. Long Marsh lies about $10 \mathrm{~km}$ to its north, on the Macquarie River.

Efforts to use the water resources of Tooms Lake may have been the first expression of interest in irrigation from the Macquarie. (Gowlland 1980 , p.62) mentioned that a weir, $1.5 \mathrm{~m}$ high, had been built across the outlet of the lake before 1840 , but he did not indicate its purpose - for irrigation or in aid of a water-mill downstream. Cotton's interest in Tooms Lake was shown indirectly and directly in his paper (Cotton 1842a, pp.86,178). He described the embankment at the lake as $4.5 \mathrm{~m}$ high, and gave other details which suggest that he was familiar with it.

Cotton's first visit to Tooms lake is unlikely to have been before mid-1839. It could have occurred while he was the guest of a family "in the centre of the island', as his daughter put it, or in the Midlands. While in that region he must have met William Kermode, of Mona Vale, and found that they had a common interest in irrigation. Strzelecki, who lived in Tasmania from July 1840 to September 1842. reported that Cotton helped Kermode with one undertaking involving drainage and a nother for irrigation which depended on water conserved in a basin on the Macquarie River (Strzelecki 1845 , pp.384-5). The details given by that writer concerning the works at that basin agree with Cotton's description applying to Tooms Lake. A beneficial flow of the Macquarie after the opening of the sluice gate at Tooms Lake was reported in the Launceston Advertiser of 11 February 1841.

Captain Cotton's interest in Tasmanian irrigation was apparently public knowledge well before his paper was published. In 1840, David Burn then living in England (Pike 1966-67, v.1, p.112)introduced Captain Cotton to readers of the London Colonial Magazine in his articles on Tasmania. The instalment published in December 1840 states:

'The principal source of the Macquarie River is Tooms Lake. This place has recently been surveyed by Captain Cotton ... who reports upon the facility of constructing an immense reservoir ... capable of supplying the wants of numerous flour mills, and of irrigating about 40,000 acres ( 18000 ha) during the summer' (Burn 1840b).

There is also the editorial in the Hobart Town Courier of 16 April 1841 , which is related to the news of February 1841 mentioned above. It states:

'... owing to the plan adopted of damming the narrow outlet of Toomb's Marsh, as suggested and contrived by Captain Cotton, the stream of the Macquarie has continued to flow most abundantly during the last summer months ...'

The timing of both these statements shows that they concern Cotton's activity during his first visit. Although both reports name the same locality, the associated activities attributed to Cotton are reported differently. The reliability of the account in the Hobart newspaper is not in question, but details in Burn's statement suggest confusion. Thus Cotton did not claim Tooms Lake as the principal source of the Macquarie, and the capability for irrigation that Cotton attached to Tooms Lake is only one-seventh of the area noted above by Burn.

Much informaton has been published concerning the other, abortive effort at irrigation from the Macquarie, involving a large reservoir at Long Marsh. This is the scheme associated by Roberts (1924) with Major (Hugh) Cotton (Pike 1966-67. v.1, p.250), whose involvement is well established. Although Arthur Cotton gave no hint in his paper of a scheme on the Macquarie other than one based on Tooms Lake, it appears that he was involved in the Long Marsh scheme before the arrival of his brother, Hugh Cotton, in Tasmania. A letter from Philip Smith to Mr. Spode, quoted by Gowlland (1980, p.69) reported his return from Tooms Lake 
and Long Marsh 'in company with Mr. Kermode, Captain Cotton, and Mr. Jackson'. The date of the letter was given as 13 October 1843 , at which time Arthur Cotton was back in India; the original letter is now known to have been written in October 1842 (R.W. Gowlland, personal communication). Arthur Cotton's interest in using Macquarie River water other than from Tooms Lake is reported by Gowlland (1980, p.64) as going back to 1840 and involving an association with landowners in the Midlands. This information suggests that details in Burn's statement above related to Long Marsh, not Tooms Lake.

\section{Other Developments}

The success in 1841 of the Tooms Lake scheme helped to focus public attention on irrigation. Sir John Franklin spoke on this matter while in the Midlands later that year, as reported in the Launceston Advertiser of 14 October 1841. The Cornwall Chronicle, another Launceston newspaper, reported on 9 April 1842 that there was a 'mania for irrigation' and held the diversion of stream water for this purpose responsible for the problems then facing millers dependent on water power. On the other hand, Strzelecki (1845, pp.385-6) was apparently aware of only a few irrigators in 1840-42.

Cotton's intentions of cond ucting irrigation on a small farm during his second visit (Hope 1900 , p. 24) are not confirmed by his later Tasmanian paper (Cotton 1842b), which reported only his development of a steam-driven digging machine.

\section{DISCUSSION AND CONCLUSIONS}

Although Tasmania is well watered in comparison with other parts of Australia and has no widespread need for irrigation, there were by the late 1830 s some inducements to irrigate, particularly in districts where plant growth is likely to suffer from summer drought. Conditions in the island at the time of Arthur Cotton's first visit were propitious for development of irrigation. The colony was then experiencing an economic boom, largely due to the effects of a serious drought in New South Wales and the establishment of new pastoral runs in Victoria and South Australia (Hartwell 1954, pp.212-5). Secondly, some success with irrigation of crops and pastures had been gained in the colony. Finally, with 26 water-mills in 1829 and 39 in 1839 (Linge 1979, p.130), Tasmanians had gained experience of harnessing the local water resources, and at least in the case of Captain Fenton (Burn 1840a) there was ability to combine milling and irrigation.
Arthur Cotton's influence on Tasmanian ir rigation should not be judged solely by reference to his long paper, which - perhaps from modesty, fear of jeopardising his opportunities for long leave on sick certificate, or for another reason - did not fully represent his activities in the colony. His views found a receptive audience. Among it were members of the Tasmanian Society, including Lillie (1842) Strzelecki (1845) and Sir John Franklin; landowners; and some journalists. Cotton's work on behalf of landowners was recognized by the Midland Agricultural Association which, as reported in the Hobart Town Courier of 7 January 1842, conferred honorary membership on him, a privilege also extended then to Strzelecki, who had other agricultural interests besides irrigation.

Cotton's expert knowledge, enthusiasm for irrigation, and capacity for communication, contributed to local progress with irrigation. The Tooms Lake scheme, with which he was involved, soon proved an advantage to landowners in the district and its success apparently encouraged others to irrigate in 1842. The persistence of irrigation from Tooms Lake was indicated by Bruni (George A. Brown) in his article on irrigation in Tasmania, in the Melbourne Australasian of 3 November 1883. The report by Martelli (1861) shows that by 1860 irrigation had been undertaken on at least 20 estates, some of which then accounted for a total of approximately 250 ha under irrigation.

Strzelecki came to Tasmania at the close of Arthur Cotton's first visit; he showed interest in irrigation though not as an initiator. Hugh Cotton arrived during his brother's second visit, publicised. irrigation (Cotton 1843) with extensive reference to his brother's paper, and was involved officially in the Long Marsh scheme. He had considerable experience of Indian irrigation and made plans for extensive irrigation from Long Marsh and other basins (Cotton 1844), but these were abandoned because of financial problems (Gowlland 1980, pp.70-3). Thus there appears to have been no-one in Tasmania who rivalled Arthur Cotton in success with extending irrigation in the $1840 \mathrm{~s}$.

\section{ACKNOWLEDGMENTS}

Mary McRae of the Archives Office of Tasmania, and I.A. Baxter of the India Office Library and Records, London, were most helpful in providing details of Arthur Cotton's movements between India and Australia. Other help, particularly by access to newspapers, was given by officers of the La Trobe Library, Melbourne; the Mitchell Library, Sydney; and the State Library of South Australia. My sister, Louisa Hamilton, provided useful information from searches in Hobart and London. 


\section{REFERENCES}

ANON., 1972: Bur. Meteorol. Climatic Survey. Midland, Region 4, Tasm. Aust.Govt.Publ.Serv,; Canberra.

BACK HOUSE, J, 1843: A NARRATIVE OF A VISIT TO THE AUSTRALIAN COLONIES. Hamilton Adams; London.

BETHELL, L.S., n.d: THE VALLEY OF THE DERWENT. Govt.Printer; Hobart.

BURN, D., 1840a: Scenery - The Derwent River, etc. Colonial Magazine, 2: 181-96.

$1840 \mathrm{~b}$ : Scenery of the Shannon River and Lake Clarence. Colonial Magazine, 3: 457-71.

COTTON, A.F. (T), 1842a: On irrigation in Tasmania. Tasm. J.Nat.Sci. 1: 81-93, 161-87.

1842b: Account of a proposed steamdigging machine. Tasm.J.Nat.Sci., 1: 295-99.

COTTON, H.C., 1843: Lecture on irrigation ... July 14, 1843. Mechanics Inst:: Hobart.

1844: Irrigation. Major Cotton's reports and estimates. Appendix to Pap. No. 42. J. House Assembly Tasm. 1861, vol.;7.

DEAKIN, A., 1892: Irrigation in Australia, pp. 81-96 in GREVILLE, E. (Ed.) YEAR BOOK OF AUSTRALIA FOR 1892. Yearbook of Aust.Publ. Co.; Sydney.

DICKINSON, H.W. 1963: A SHORT HISTORY OF THESTEA M ENGINE. 2nd. Ed; Cass, London.

GOWLLAND, R.W., 1980: The Long Marsh Dam Affair. pp.62-73 in SOME VAN DIEMENS $L A N D$ AFFAIRS. Gowlland; New Norfolk.

HARTWELL, R.M. 1954: ECONOMIC DEVELOP MENTOF VAN DIEMENS LAND 1820-1854. Melb. Univ. Press: Melbourne.
HENDERSON, J., 1832: OBSERVATIONS ON THE COLONIES OF NEW SOUTH WALES AND $V A N$ DIEMENS LAND. Baptist Mission Press; Calcutta.

HODSON, V.C.P., 1927: LIST OF OFFICERS OF THE BENGAL ARMY 1758-1834. Part 1. Constable; London.

HOPE, E.R., 1900: GENERAL SIR ARTHUR COTTON. Hodder \& Stoughton; London.

LILLIE, J., 1842: Introductory paper. Tasm.J.Nat.Sci., $1: 1-13$.

LINGE, G.J.R., 1979: INDUSTRIALAWAKENING. A GEOGRAPHYOF AUSTRALIAN MANUFACTURING 1788-1890. A.N.U. Press; Canberra.

MARTELLI, A., 1861. Irrigation. Report of Signor Martelli, C.E. Pap. No. 43. J:House Assembly Tasm. vol. 7.

PIKE, D. (Ed.), 1966-67: AUSTRALIAN DICTION$A R Y$ OF BIOGRAPHY, vols 1 \& 2. Melb. Univ. Press; Melbourne.

ROBERTS, S.H., 1924: HISTORY OF AUSTRALIAN LAND SETTLEMENT(1788-1920). Macmillan \& Melb.Univ.Press: Melbourne.

SANDES, E.W.C., 1935: THE MILITAR Y ENGINEER IN INDIA, vo.2. Inst. R. Eng.; Chatham.

SCARBOROUGH, D.H., \& BRAND, I.M., 1975: Long Marsh Dam ... an early irrigation project. Tasm.J.Agric. 46: 227-30.

STRZELECKI, P.E.De, 1845: PHYSICAL DESCRIPTION OF NEW SOUTH WALES AND VAN $D I E M E N S L A N D$. Longman; London.

VIBART, H.M., 1894: $A$ DDISCOMBE: ITS HEROES AND MEN OF NOTE. Constable; London.

(accepted Jan. 14, 1985). 